\title{
Remigiusz Sobański
}

\section{Prawo kanoniczne a kultura prawna}

Prawo Kanoniczne : kwartalnik prawno-historyczny 35/1-2, 15-33

1992

Artykuł został zdigitalizowany i opracowany do udostępnienia w internecie przez Muzeum Historii Polski w ramach prac podejmowanych na rzecz zapewnienia otwartego, powszechnego i trwałego dostępu do polskiego dorobku naukowego i kulturalnego. Artykuł jest umieszczony w kolekcji cyfrowej bazhum.muzhp.pl, gromadzącej zawartość polskich czasopism humanistycznych i społecznych.

Tekst jest udostępniony do wykorzystania w ramach dozwolonego użytku. 


\section{KS. REMIGIUSZ SOBAŃSKI}

\section{PRAWO KanONiczNe a KUltura PRAWNa *}

\section{Uwagi metodologiczne}

\section{Wielość plaszczyzn badawczych}

W wielkiej Enciclopedia del Diritto ${ }^{1}$ nie znajdujemy hasła „kultura prawna”. W referacie na temat ,prawo kanoniczne a kultura prawna” trudno wdawać się w próby definiowania kultury, niemniej jednak wprowadzenie do dyskusji nie może nie wytyczyć jej granic. Roboczo więc przyjmijmy, że kultura to całokształt materialnego i duchowego dorobku ludzkości lub jakiejś społeczności, wytworzonego w ogólnym rozwoju historycznym lub $w$ jakiejś epoce $i$ charakteryzującego ogólny poziom rozwoju odnośnej społeczności ${ }^{2}$. „W skład tak pojętej kultury wchodzą systemy norm i wartości, wierzenia, wszelkie społecznie wyuczone zachowania, wzory tych zachowań oraz ich wytwory" ${ }^{3}$. Mówiąc o kulturze prawnej mamy przeto na myśli normy, wartości, zachowania i ich skutki, o ile wiążą się z prawem. Jest ona zjawiskiem złożonym, które można badać na następujących plaszczyznach: ${ }^{4}$

a) Płaszczyzna logiczno-językowa: Badania dotyczą źródeł istnienia i poznania prawa, jego aparatury pojęciowej, sposobu konstruowania systemów prawa, struktury tych systemów, faktów prawotwórczych, roli egzegezy. $\mathrm{Na}$ tej płaszczyźnie zainteresowania badacza skupiają się więc na tekstach, w których kultura prawna znajduje swój wyraz.

b) Płaszczyzna aksjologiczna: chodzi o wartości i oceny stojące u podstaw odnośnej kultury prawnej, o dążenia prawodawcy i zamierzone cele, politykę prawa, dyrektywy i zasady prawa, oceny preferencyjne w przypadku kolizji dóbr. Ostatecznie oko badacza usiłuje dostrzec ideowe (filozoficzne, teologiczne, ekonomiczne, polityczne) założenia prawa.

c) Płaszczyzna psychologiczno-społeczna lub - w zależności od pojmowania rozgraniczenia między psychologią i socjologią - płaszczyzny

* Polska wersja referatu wygłoszonego 2. 5. 1990 na międzynarodowym seminarium n. t. Nauki prawne i prawo kanoniczne na Uniwersytecie w Turynie. Tekst oryginalny w: Scienza giuridica e diritto canonico, ed. Rinaldo Bertolino, Torino $1990121-150$.

111 , Milano 1962.

- A. Podsiad, Z. Więchowski, Maly slownik terminów i pojęć filozoficznych dla studiujacych filozofię chrześcijańska, Warszawa 1983, 192 ns.

3 Tamze.

- K. Opałek, J. Wróblewski, Zagadnienia teorii prawa, Warszawa 1959, 326-336; Z. Ziembiński, Teoria praw'a, Warszawa-Poznań 1978, 11-14. 
psychologiczna i społeczna. Chodzi o zachowania podmiotów prawa i osób związanych z prawem: Czyli: reakcje spoleczne na prawo, znajomość i aprobata prawa, jego skuteczność, stopień zaufania do prawa, funkcjonowanie organów stosujących prawo, zmiany społeczne spowodowane przez stosowanie prawa.

Wielość płaszczyzn badawczych kultury prawnej wiąże się ze złożonością kultury i ze złożonością zjawiska prawnego. Tę złożoność kultury prawnej trzeba mieć na uwadze, gdy stawiamy pytanie o miejsce w niej prawa kanonicznego. Czym innym jest bowiem obecność prawa kanonicznego jako składnika praw obowiązujących w danej społeczności (utrumque ius), obecność $z$ walorem prawnym niektórych norm na forum świeckim (np. kanonicznego prawa małżeńskiego), obecność jako historyczna dyscyplina uniwersytecka, obecność jako jedynie wewnętrzne prawo Kościoła (przy czym w tym przypadku może ono pośrednio wpływać na praktykę prawa $w$ danej społeczności albo też zgola pozostawać bez wpływu nawet na życie religijne). W szczególności wydają się zaniedbane płaszczyzny psychologiczna i socjologiczna obecności prawa kościelnego w kulturze prawnej, a przecież to na nich dokonuje się współcześnie interferencja prawa kościelnego i świeckiego i od nich zależy ostatecznie profil odnośnej kultury prawnej.

W zależności od stawianych pytań i stojących do dyspozycji metod badawczych można by wyodrębnić inne jeszcze plaszczyzny. Wydaje się jednak, że wskazane trzy (wzgl. cztery) są z punktu widzenia naszego tematu wystarczające (nie wydaje się np. celowe wyodrębnienie płaszczyzny ekonomicznej czy politycznej). Na każdej z nich badania można prowadzić $w$ aspekcie diachronicznym i synchronicznym.

\section{Wielość kultur prawnych}

Podejmując temat prawo kanoniczne a kultura prawna nie można nie zwrócić uwagi na wielość kultur prawnych. Zróżnicowanie to sięga tak daleko, że szereg szkól zaprzecza możliwości porównywania stojących u podstaw tych kultur pojęć prawa (,Jak można porównywać kultury prawne, jeśli brak wspólnej, dającej się zweryfikować $w$ nich, definicji prawa?"). Wśród tych szkół wyróżniają się trzy stanowiska ${ }^{5}$ :

a) Stanowisko, wedle którego każda kultura prawna opiera się na własnym pojęciu prawa, którego nie da się zdefiniować z zewnątrz (,folksystems"-Bohanann). Według tego poglądu kulturę prawną, porządek prawny można badać tylko od wewnątrz (,to co wschodnie, widzieć od wschodu" - Vollenkofen), a więc posługując się jej pojęciami, kryteriami, wyobrażeniami.

${ }_{5}^{5} \mathrm{~W}$. Fikentscher, Syneëpik und eine syneëpikische Definition des Rechts, w: Enstehung und Wandel rechtlicher Traditionen, Hg. W. Fikentscher, H. Franke, O. Köhler, Freiburg-München 1980, 52-120, szczeg. 94-111. 
b) Teorie transpozycyjne, które w założeniu pozwalają badać kultury prawne $z$ zewnątrz $i$ to przy pomocy zewnętrznych (a więc właściwych kulturze prawnej badacza, a nie kulturze badanej) pojęć i wyobrażeń, które nanosi się jako narzędzie badawcze na poznawaną rzeczywistość. Uzasadnia się takie postępowanie tym, że badacz może komunikatywnie referować u siebie wyniki badań nad obcą kulturą prawną tylko przy pomocy aparatu pojęciowego zrozumiałego $\mathrm{w}$ jego własnym środowisku. Trzeba tu jednak zauważyć, że porównanie to dokonuje się jedynie w oczach badacza, który uzyskane ustalenia klasyfikuje wedle własnych, badanej kulturze obcych kryteriów, wtłacza je w aprioryczne ramy, dopasowuje do właśnej kultury. Wyniki jego badań są zrozumiałe w jego własnym środowisku, wątpliwe jest jednak, czy byłyby zrozumiałe w środowisku badanym oraz w innym jeszcze ,neutralnym" środowisku. Transpozycja pojęć nie jest tym samym, co porównanie pojęć. Dlatego właśnie zalicza się teorie transpozycyjne do stanowisk zaprzeczających porównywalność kultur prawnych, mimo że wlaśnie te teorie są w praktyce szeroko stosowane. Używane metody zależą z kolei od przyjętego pojęcia prawa, które się transponuje. Są to (a) jakaś idea prawa (np. prawo natury) jako fenomenu pozwalającego ksztaltować rzeczywistość przy pomocy środków prawnych; (b) nominalistyczne pojęcie prawa, mające wtedy tylko funkcje słowną (Williams); (c) prawo definiowane jako narzędzie kontrolne rzeczywistości, a więc droga pośrednia między (a) i (b) czyli między kształtującą rzeczywistość ideą prawa oraz ksztaltującą prawo rzeczywistością (Stammler).

c) Stanowiska, wedle których $w$ niektórych kulturach prawnych w ogóle nie można mówić o prawie, a to dlatego, że to, co w nich uznaje się za prawo, nie jest prawem. Oczywiste jest tutaj zacieśnienie pojęcia prawa do tego, co badacz za prawo uważa: co nie odpowiada jego pojęciu prawa, po prostu nie jest prawem. Tą drogą zaprzecza się istnieniu prawa w niektórych, zwłaszcza ,prymitywnych" kulturach.

Stanowiska przyjmujące porównywalność kultur prawnych zakładają możliwość dojścia do wspólnej definicji prawa. Powstaje wtedy pytanie o kryteria tej definicji. I tu napotykamy szereg teorii:

a) Teorie przyjmujące jedno kryterium. $Z$ takimi teoriami niewiele można począc $i$ dlatego nie odgrywają one $w$ praktyce większej roli.

b) Tearie przyjmujące wielość kryteriów. Np. teoria L. Pospisila ${ }^{6}$ wyodrębniająca cztery kryteria: (a) prawo wyraża się w decyzji jakiegoś autorytetu, (b) określa obligatoryjnie stosunek między stronami, (c) ma być generalnie i regularnie stosowane, (d) jest wyposażone w sankcję. Okazuje się jednak, że żadne $z$ tych kryteriów nie jest bezdyskusyjne. Autorytet $w$ sensie leadership nie odgrywa roli w prawie międzynarodowym. O obligatoryjnym stosunku między stronami nie można mówić w tych kulturach prawnych, które są zorganizowane wertykalnie (Daleki Wschód), podobnie jak cechy generalnosici i regularności brak w tych

- Antropology of Law. A Comparative Theory, New Haven 1971, 7.

2 - Prawo Kanoniczne $\mathrm{nr} 1-2$ (1992) 
kulturach, które odnoszą prawo zawsze do konkretnych przypadków, dopuszczając najwyżej ich analogię. Nie trudno też wskazać, że również kryterium sankcji nie zawsze sprawdza się.

c) Teorie, wedle których porównanie winno być prowadzone na płaszczyżnie metateoretycznej, tzn. należy wyjść nie od jakiejś teorii prawa, lecz od sposobu myślenia („Denkarten”) właściwego danej kulturze. Poznanie prawa zróżnicowanych kultur wymaga wniknięcia w tamtejsze rozumienie czasu, historii, przyczynowości, prawideł języka, religii, ekonomii. Badacz winien stanąć niejako w pośrodku badanej kultury, zaznajomić się z protegowanymi tam wartościami i przyjętymi ocenami. Chroni go to przed eliminowaniem ustaleń nie pasujących do koncepcji właściwych innym kulturom i pozwala wydobyć oryginalne rozumienie prawa kultury badanej, nieskażone obcymi wyobrażeniami.

Ten szeroki wywód metodologiczny prowadziłem nie po to, by wyważać otwarte drzwi i uzasadniać, że badania nad miejscem prawa kościelnego w kulturze prawnej wymagają odniesienia do konkretnej kultury. Chociaż jest to oczywiste, to jednak nie zawadzi zwrócić uwagi, że kanoniści do dziś, gdy piszą o stosunku prawa kościelnego do świeckiego, pozostają w ramach klasycznego problemu ius canonicum et ius civile (wyrosłego z problemów średniowiecznej respublica christiana), skutkiem czego prawo własnego kraju czy własnego kręgu kulturowego traktują jako prawo świeckie tout court. Wpływa na to niewątpliwie optyka problemu, jaki stawiali, mianowicie wyświetlanie wzajemnych wpływów - a wiadomo, że byly to wpływy prawa rzymskiego i germańskiego ${ }^{7}$. Dopiero świeżej daty są prace konfrontujące prawo kanoniczne $z$ common law ${ }^{8}$. Ze względu na to, że kultura prawna krajów pierwszego i drugiego świata rozwijająca się zresztą $w$ kontakcie $z$ chrześcijaństwem - da się mimo wszystkich różnic sprowadzić do wspólnego mianownika, można uzyskane ustalenia odnoszące się np. do kultury prawnej zachodniej Europy potraktować jako modelowe i nadać im charakter zasadniczy.

Do wygłoszenia tego wstępnego dyskursu o metodzie sklonił mnie jednak przede wszystkim fakt, że $w$ badaniach nad stosunkiem prawa kościelnego do świeckiego przyjmuje się często z góry ustalone kryteria prawa, a czasem nawet po prostu jego nominalną definicję. Właśnie aprioryczne pojęcie prawa doprowadziło R. Sohma do tezy o sprzeczności między Kościołem i prawem. Zafiksowane kryteria prawa zmusily też marksistowskich teoretyków prawa do traktowania prawa kościelnego per non est. Mówię tylko o konsekwencjach poznawczych, ale - gdy chodzi o prawo żywe - pociągają one za sobą próby uformowania go według egzogennych kryteriów.

7 „Das römisch geprägte Kirchenrecht”, „das germanisch geprägte Kirchenrecht" - H. E. Feine, Kirchliche Rechtsgeschichte, Köln-Graz 4, 1964.

${ }_{8}$ F. G. Morrisey, Les élements du Droit Anglo-Saxon qui pourraient être incorporés au nouveau Droit canonique de procedure, Mon. Eccl. 101 (1976) $240-253$. 


\section{Aspekty historyczne}

\section{Prawo kanoniczne w kulturze prawnej Europy nowożytnej}

Istotne cezury czasowe wyznaczające nasz problem to (a) początki średniowiecznej symbiozy iuris canonici et iuris civilis oraz (b) początki nowoczesnej organizacji państw na kontynencie europejskim wokół r. 1500. To przejście od porządku średniowiecznego do państw książęcych $z$ ich aparatem urzędniczym wyznacza ramy problemu miejsca prawa kanonicznego w kulturze prawnej. U początku tego okresu mamy w Italii, Hiszpanii, Francji i Niemczech setki lokalnych coutumes. Czynnikiem jednoczącym było recypowane prawo rzymskie, stanowiące podstawę uniwersyteckiego wykształcenia prawniczego $\mathrm{i}$ instrument interpretacji również praw lokalnych. Równocześnie traci na znaczeniu prawo kanoniczne, które od soboru trydenckiego staje się wewnętrznym prawem Kościoła katolickiego (co nie przeszkadza, że niektóre jego normy np. prawa rodzinnego czy procesowego - były stosowane nawet w krajach protestanckich aż do XIX w.) ${ }^{9}$. Recepcja prawa rzymskiego obejmuje państwa zachodniej i środkowej Europy po Szwecję i Litwę i prowadzi do kręgu kulturowego tzw. ius commune (obok angielskiego common law). $\mathrm{Na}$ obszarze tego ius commune wyrastają najpierw w XVIII w. kodyfikacje ancien régime, a następnie wielkie kodyfikacje XIX w. Do czasów ancien régime czynnikiem rozwojowym prawa jest głównie orzecznictwo i communis opinio doctorum, dzięki czemu nie traci się z pola widzenia prawa kanonicznego (zwłaszcza w mierze, w jakiej niektórzy uczeni niemieccy widzą $\mathrm{w}$ nim przekaźnika starego prawa germańskiego) ${ }^{10}$. Ta sytuacja zmienia się radykalnie na gruncie oświeceniowej koncepcji podziału władzy: prawo jest odtąd produktem władzy ustawodawczej. Jego cechy to racjonalność i efektywność, co powoduje dynamiczny rozwój nauk prawnych i rozwój organizacji państwa ${ }^{11}$.

Aczkolwiek w XIX w. w tych państwach prawo kanoniczne nie ma już na forum państwowym żadnej mocy prawnej, to jednak w krajach niemieckich rozkwita nauka prawa kanonicznego. Przyczyniła się do tego najpierw historyczna szkoła prawa. Według F. C. v. Savigny'ego ze względu na światowy zasięg chrześcijaństwa nie można prawa kanonicznego zaliczyć ani do prawa publicznego ani do prawa prywatnego, lecz tworzy ono odrebny obszar 0 wielu punktach stycznych z prawem państwowym ${ }^{12}$. Tym samym wytyczono precyzyjną granicę między prawem

- V. Wolter, Ius canonicum in iure civili. Studien zur Rechtsquellenlehre in der neueren Privatrechtsgeschichte, Köln-Wien 1975.

${ }_{10}$ O. v. Gierke, Deutsches Privatrecht, Leipzig-München 1895, I, 15.

11 Jest rzeczą charakterystyczną, że podręczniki metodologiczne nauk prawnych zawierające także część historyczną obejmują ostatnie 150 lat. Np. K. Larenz, Methodenlehre der Rechtswissenschaft, Berlin-Heidelberg-New YorkTokio 1983.

12 System das heutigen Römischen Rechts, I, Berlin 1840, 27. 2* 
kanonicznym i "cywilnym" jako przedmiotem nauk prawnych i prawnohistorycznych, czego wzorcowym przykładem są prace takich autorów jak J. F. Schulte, E. L. Richter, E. Friedberg, P. Hinschius.

Nauki prawne wypracowały też kryteria prawa. Ich aplikowanie do prawa kościelnego nie nastręczało trudności metodologicznych, gdyż w Europie prawo kanoniczne nie bylo kulturowo obce. Wręcz przeciwnie, ze względu na jego miejsce w formowaniu się europejskiej kultury prawnej będzie ono na obszarze dawnego ius commune długo jeszcze dyscypliną uniwersytecką uznawaną za konieczną dla pełnej formacji prawniczej. $\mathrm{Na}$ wydziałach prawa na północ od Alp wykłada się je w ramach historii prawa, jako ius vigens jest ono przedmiotem wykladu na wydziałach teologicznych. Pozostało więc dyscypliną uniwersytecką, a jego miejsce w kulturze prawnej bylo mocne.

Pociągnello to za sobą konieczność dostosowania się do wymogów tej kultury. Kanoniści na północ od Alp mieli w tym zakresie już odpowiednie doświadczenie. Sprowokowani kanonistyką józefińską kanoniści - związani głównie $z$ uniwersytetem $w$ Würzburgu - przejęli metody uznane na uniwersyteckich katedrach doby oświeceniowej. Uczeni ci - jak i nawiązująca do nich nauka kościelnego prawa publicznego - usiłowali zapewnić suwerenną obecność Kościoła jako bytu prawnego na bazie filozofii społecznej. Z kolei niemieccy kanoniści XIX w. podjęli się udanego wysilku doprowadzenia kanonistyki do metodologicznego standardu ówczesnych nauk prawnych. Dzięki dziełom G. Phillipsa, J. F. v. Schultego, R. v. Scherera, F. Heinera, J. B. Sägmüllera, J. B. Haringa kanonistyka niemiecka była up-to-date ówczesnej kultury prawnej ${ }^{13}$.

Wydaje się, że powyższe przypomnienia wystarczają dla ustawienia problemu „prawo kanoniczne w kulturze prawnej”. Są to ramy wyznaczające teren badań. Osadzilem je na północ od Alp dlatego, że teorie polityczne i prawne, które wpłynęły decydująco na współczesną europejską kulturę prawną, po roku 1500 rodziły się $w$ krajach, które z punktu widzenia Włoch nazywa się nordyckimi ${ }^{14}$.

\section{Prawo kanoniczne $w$ kulturze prawnej Polski}

$\mathrm{Na}$ zasadzie ekskursu pozwolę sobie teraz rzucić okiem na miejsce prawa kanonicznego $\mathrm{w}$ polskiej kulturze prawnej. Trzeba przypomnieć, że przyjęcie chrztu przez Polan w r. 966 było aktem o dużej wadze politycznej. Wzrósł przez to autorytet władzy monarszej, organizacja kościelna usprawniła funkcjonowanie państwa. Struktury kościelne stały się ważnym uzupełnieniem państwowych, arcybiskupstwo gnieźnieńskie czynnikiem jednoczącym, a biskupi zajmowali wysokie stanowiska państwowe. Do XII w. synody prowincji gnieźnieńskiej byly zarazem zjazdami

13 A. M. Rouco Varela, Allgemeine Rechtslehre oder Theologie des kano: nisches Rechts? Erwägungen zum heutigen Stand einer theologischen Grundlegung des kanonischen Rechts, Archiv f. kath. Kirchenrecht 138 (1969) 95-113.

14 Por. P. A. d'Avack, Trattato di diritto canonico, Milano 1980, 34. 
państwowymi. Powszechnie stosowano przywilej sądu (z wyjątkiem spraw o dobra ziemskie i o zdradę), sądom kościelnym podlegały sprawy duchowe i z duchowymi związane, w tym i małżeńskie. W dziedzinie prawa małżeńskiego wpływ prawa kanonicznego był szczególnie mocny, zwlaszcza w sprawach, które biskupi uznawali za ważne (jedność i nierozerwalność małżeńska, przeszkoda pokrewieństwa, ochrona uprawnień kobiety) ${ }^{11}$. Jak wszędzie w Europie, prawo małżeńskie było opanowane przez kanoniczne. Prawo kanoniczne stosowano zresztą nie tylko w sądach kościelnych, ale oddziaływało ono na wszystkie gałęzie prawa ziemskiego (ius terrestre). Sferę zobowiązań, testamenty rozpatrywano w oparciu o prawo kanoniczne, stosując przy tym zresztą kanoniczną procedure sądową. Od początków XII w. posługiwano się Collectio Tripartida, od XIII w. wszedł w użytek Dekret Gracjana i dekretały. Na nim opierało się prawo partykularne synodów prowincjalnych i legackich. Wprost dotyczyly one spraw kościelnych, ale ze względu na przekonanie, że państwo polskie jest prawowiernym państwem chrześcijańskim, oraz tym samym - ze względu na tożsamość pojąc „obywatel” i „chrześcijanin" oddziaływały pośrednio na cale społeczeństwo i na ustrój państwa ${ }^{16}$.

Polska średniowieczna była państwem stanowym. Każdy stan rządzil się swoim prawem: szlachta prawem ziemskim (ius terrestre), duchowieństwo kanonicznym, mieszczanie i wolni chłopi prawem magdeburskim (ius municipale). W miarę rozwoju prawa pisanego utrwalał się wpływ prawa niemieckiego (Sachsenspiegel dołączony do statutów Łaskiego z r. 1506) i kanonicznego. To ostatnie przenikało wszystkie dziedziny prawa ziemskiego, czemu sprzyjało też obsadzanie kancelarii królewskiej duchownymi. Do końca XV w. wykładano na uniwersytecie krakowskim jedynie prawo kanoniczne ${ }^{17}$. Recepcja prawa rzymskiego ${ }^{18}$ dokonywała się w prawie miejskim (wg glossy Accursiusa), gdzie poslugiwano się nim przy interpretacji prawa magdeburskiego. Napotykała natomiast opór ze strony szlachty, a więc $\mathrm{w}$ prawie ziemskim. Szlachta podkreślała, że Polacy rządzą się własnym prawem, a nie cesarskim. Ponadto widziano $\mathrm{w}$ prawie rzymskim (princeps legibus solutus!) zagrożenie swobód i przywilejów szlacheckich. Tych obaw nie rodzilo prawo kanoniczne.

${ }_{15}$ M. Żurowski, Wplywy chrześcijańskie na pierwotne prawo polskie $w$ sprawach makzeńskich, Pr. Kan. 18 (1975) n. 1-2, 73-87.

16 W. Sawi cki, w: Historia Kościola w Polsce, red. B. Kumor, Z. Obertyński, Poznań-Warszawa $1974, \mathrm{I}, 70-73,128-130$.

$17 \mathrm{~W}$ akcie fundacyjnym uniwersytetu Kazimierza Wielkiego z 12. 5. 1364 na jedenastu profesorów ośmiu miało kierować katedrami prawa - 3 prawa kanonicznego (Dekretu Gracjana, dekretalów Grzegorza IX oraz Liber sextus i Klementyn), 5 prawa rzymskiego. Prawo rzymskie zaczęto wykładać dopiero od r. 1533 - T. Pawluk, Z zagadnień kanonistyki polskiej, Prawo Kan. 16 (1976) n. $3-4,162$ ns.

${ }_{18} \mathrm{~W}$ rejestrach uniwersytetu bolońskiego nazwiska Polaków znajdujemy od połowy XIl w. Ok. r. 1257 ukonstytuowala się tam natio polona - T. Pawluk, tamże 163. 
Miejsce, jakie we wszystkich podręcznikach historii prawa Polski przedrozbiorowej - także $\mathrm{w}$ tych, które pisano w czasie obowiązywania metodologii marksistowskiej - zajmuje prawo kanoniczne, jest dowodem jego inspirującej obecności w polskiej kulturze prawnej.

Mocno osadzone było prawo kanoniczne również w kulturze prawnej drugiej rzeczypospolitej (1918-1939). Wiązało się to niewątpliwie z pozycją, jaką w państwie polskim zajmował Kościół katolicki, uznany w art. 114 Konstytucji z r. 1921: „Wyznanie rzymsko-katolickie, będące religią przeważającej większości narodu, zajmuje $w$ państwie naczelne stanowisko wśród równouprawnionych wyznań. Kościół rządzi się własnymi prawami". Zasada stojąca u podstaw konkordatów zawieranych od XIX w. „religio catholica romana conservabitur cum is iuribus et praerogativis, quibus frui debet ex Dei ordinatione et canonicis sanctionibus", znalazła się w dosłownym, lecz mocniej jeszcze zaakcentowanym brzmieniu w konkordacie 2 r. $1924^{19}$.

Dla obecności prawa kanonicznego w kulturze prawnej drugiej rzeczypospolitej ważny był też fakt, że na uniwersyteckich wydzialach zarówno prawa jak i teologii istnialy katedry prawa kanonicznego, obsadzone przez uczonych dużego formatu, których prace $z$ zakresu historii prawa kościelnego były znane także poza granicami kraju ${ }^{20}$.

Ci spośród nich i ich następców, którzy przeżyli drugą wojnę światową, otrzymali katedry historii prawa polskiego. Katedry prawa kanonicznego na wydziałach prawa zostały zlikwidowane. Po pierwsze dlatego, że prawo kanoniczne nie odpowiadało obowiązującej definicji prawa jako narzędzia w ręku klasy panującej, po drugie zaś dlatego, że w nowej rzeczywistości społecznej religia i Kościół skazane były na wymarcie - po co więc zajmować się takim przeżytkiem. Prawo kanoniczne na wydziałach teologicznych oraz wydzialach prawa kanonicznego KUL i ATK usilowano zaliczyć do teologii, jako że nazwa „prawo” byla zastrzeżona dla prawa państwowego, a nauki uprawiane przez Kościół - jeśli to w ogóle jest nauką - to jedynie teologia ${ }^{21}$. Przeciw takiemu zaszeregowaniu energicznie protestował Wydział Prawa Kanonicznego ATK powołując się na odnośne

19 Tekst m. in. w: T. Wlodarczy k, Konkordaty. Zarys historii ze szczególnym uwzglednieniem $X X$ wieku, Warszawa 1974, 423-431.

${ }_{20}$ B. Ulanowski, J. Brzeziński, A. Vetulani w Krakowie, W. Abraham we Lwowie, B. Wilanowski w Wilnie, T. Silnicki w Poznaniu, J. Wiślicki, H. Insadowski, J. Roth, G. Michiels w Lublinie, J. Sawicki w Warszawie. Por. R. Sobański, Methodologische Gemeinsamkeiten der deutschen und polnischen Kanonistik, w: Deutsch-polnische Universitätstage. Vorträge, Reden und Ansprachen eines Symposiums im November 1988, Hg. B. Schultze, K. Sauerland, Mainz 1989, 96-104. Por. też: J. Sawicki, Die Entwicklung der Kirchenrechtswissenschaft in Polen 1978-1957, Österr. Archiv f. Kirchenrecht 9 (1958) 243-269; P. Hemperek, Kanonistyka polska w 60-leciu wolnej Polski (1918-1978), Pr. Kan. 24 (1981) n. 1-2, 41-77; T. Pawluk, Z zagadnień kanonistyki polskiej, 198-212.

${ }_{21} \mathrm{~W}$ wykazie dyscyplin akademickich wszystkie określono rzeczownikiem „nauka” i dodanym doń przymiotnikiem (np. nauki prawne, medyczne), jedynie teologię określono tym jednym wyrazem (a nie "nauki teologiczne”). 
przepisy dotyczące studiów kościelnych. Ponieważ wydziały prawa kanonicznego nie mogły nadawać doktoratów $z$ teologii, a władze państwowe nie chciały uznać prawa kanonicznego jako odrębnej dziedziny nauki, znaleziono wyjście przez zakwalifikowanie prawa kanonicznego do dziedziny nauk prawnych. W ten sposób znalazło ono potwierdzenie przynależności do kultury prawnej. Takiemu rozwiązaniu sprzyjal fakt, że prawo państwa socjalistycznego nie dysponuje kategoriami, którymi można by ująć polożenie prawne Kościoła katolickiego - w tych krajach on istniał de facto, nie de iure. Rząd polski, uznając w r. 1945 konkordat z r. 1925 za nieobowiązujący, stwierdził, że w sprawach wewnętrznych Kościół posiada autonomię. Faktycznie usilowano tę autonomię w miarę możliwości dławić, niemniej jednak oznaczało to uznanie prawa kanonicznego jako wewnętrznego prawa Kościoła. Sąd Najwyższy stał na stanowisku, że status prawny Kościoła katolickiego winien zostać uregulowany ustawą ${ }^{22}$. Co nastąpiło 17.5. 1989, a więc na kilka tygodni przed zejściem PRL ze sceny dziejów i ustąpieniu miejsca trzeciej rzeczypospolitej ${ }^{23}$.

Niezależnie od tego, co wypisywali niektórzy teoretycy prawa, prawo kanoniczne i kanonistyka przez całe te lata cieszyło się uznaniem wśród prawników. Przejawiało się to współpracą naukową (chociaż praktycznie była ona możliwa tylko $\mathrm{w}$ zakresie historii prawa), chętnym podejmowaniem przez prawników zajęć na obydwu wydziałach prawa kanonicznego, wreszcie dużym zainteresowaniem odnowionym Kodeksem Prawa Kanonicznego. Komitet Nauk Prawnych PAN wnioskował w r. 1983, by przywrócić prawo kanoniczne na wydziały prawa. Wniosek taki nie miał wtedy jednak żadnych szans.

Dodać muszę, że cywiliści wykazują duże zainteresowanie dla „teologicznych aspektów" prawa kościelnego, znacznie żywsze niż większość profesjonalnych kanonistów. Nie sądzę, by wynikało to jedynie z resentymentu do prawa socjalistycznego, ale na pewno - biorąc pod uwage rolę Kościola w tym kraju - spoglądano na nie jako na prawo kontrastowe. Dostrzegano w nim dziedzictwo europejskiej kultury prawnej, nieskażone założeniami filozofii marksistowskiej. Dodajmy, że chodzi o kraj, w którym do r. 1918 przez 130 lat obowiązywały prawa zaborów z pewnymi wyjątkami dla zaboru rosyjskiego, gdzie „w zasadzie” (z modyfikacjami, przy których zresztą wykorzystywano piśmiennictwo francuskie) ${ }^{24}$ obowiązywał wprowadzony w r. 1808 Code civil Napoleona, do którego Polacy byli także emocjonalnie przywiązani, gdyż podkreślal ich odrębność w stosunku do pozostałych ziem cesarstwa rosyjskiego ${ }^{25}$. Druga rzeczpospolita trwała zbyt krótko, by ujednolicić prawo polskie

\footnotetext{
22 Sygn, akt 4 CO 11/62 i I CR 223/63 - Orzecznictwo Sądu Najwyższego Izba Cywilna: Izba Pracy i Izba Ubezpieczeń Społecznych 1964, z. 10, p. 198. ${ }^{23}$ Dz. U. 1989 n. 29, p. 154.

${ }^{34}$ K. Só jka-Zielińska, w: Historia państwa i prawa Polski, red. J. Bardach, III: Od rozbiorów do uwlaszczenia, Warszawa 1981, 500 nss.

25 A. Stelmachowski, Wstęp do teorii prawa cywilnego, Warszawa² 1984, 5.
} 
i pozbyć się reliktów zaborców ${ }^{26}$, zaś od r. 1945 wprowadzano prawo, którego nie sposób właściwie zrozumieć bez uwzględnienia jego powiązania $z$ systemem normatywnym partii komunistycznej, a które nawet jeśli w przepisach brzmi podobnie jak prawo państw kapitalistycznych, musi ,inaczej funkcjonować, tzn. inaczej być stosowane i inaczej oddzialywać na adresatów, inaczej być przez nich przestrzegane" 27. Jeśli jeszcze zauważymy, że w obowiązującej teorii prawa praworządność uznawano za niezależną od materialnej wartości prawa (o której i tak decydują wylącznie kryteria materializmu historycznego), i że stoi się na stanowisku „immanentnej prawnej wartości legalizmu”, to łatwo zrozumieć, że prawników nie ograniczających się do roli funkcjonariuszy aparatu państwowego musiało drążyć pytanie o prawo słuszne. Odwoływanie się przez grupy opozycyjne do nauki spolecznej Kościoła tym bardziej sklaniało do zainteresowania się jego prawem i tym, co ono mogłoby wnieść do odradzającej się kultury prawnej.

\section{Odniesienie prawa kościelnego do kultury prawnej}

Nikt nie stawia problemu ,prawo włoskie a kultura prawna" (najwyżej móglby taki problem brzmieć „prawo włoskie a kultura prawna Erytrei”). Świadczy to, że samo postawienie problemu ,prawo kanoniczne a kultura prawna" sugeruje, iż znajduje się ono poza kulturą prawną, pozostaje w jakimś stosunku do niej. Istotnie, chrześcijaństwo zastało rozwiniętą kulturą prawną. W tę kulturę - jak w ogóle w całą rzeczywistość tego świata - wpisuje się chrześcijaństwo, ale nie jest ono ani społecznym ani kulturowym ewolucyjnym produktem rozwoju tego świata. Pełne respektu dla świata głosi $\mathrm{i}$ realizuje odrębność porządku religijnego i społeczno-politycznego. Ten dualizm pociąga za sobą tworzenie własnego, oryginalnego prawa przekraczającego granice narodów i kultur. „Leges sibi fecerunt" ${ }^{28}$ - biorąc przy tym $z$ zastanej kultury prawnej to, co przydatne, swobodnie jednak też kształtując własne orginalne formy i nasycając pojęcia nową treścią.

Realizacja dualizmu chrześcijańskiego napotykała trudności. Na przeciwległych biegunach znajdujemy rządy utriusque iuris wraz z pokusami hierokratycznymi oraz zaprzeczenie prawnego charakteru prawa kościelnego przez Marsyliusza z Padwy i późniejsze teorie polityczne. Próby

${ }^{26}$ R. Sobański, Das erste polnische Plenarkonzil - seine Bedeutung für den Integrationsproze $\beta$ der Bevölkerung Polens zwischen den beiden Weltkriegen, Österr. Archiv f. Kirchenrecht 26 (1975) 143-158.

${ }_{27}$ S. Ehrlich, Wstep do nauki o państwie $i$ prawie, Warszawa 1971, 223.

28 ,... pro arbitrio suo atque ut iisdem erat libitum, ita sibimet leges facerunt, quas obsevarent et per diversa varios populos congregarent" - edictum Galerii "Ut denuo sint christiani" (30.4. 311). Tekst: Lactantius, De mortibus persecutorum 34 (PI 7, 249; CSEL 27, 212). Szerzej: P. E. Pi eler, Lex Christiana, w: Akten des 26. Deutschen Rechtshistorikertages Frankfurt a. M. 26. bis 28. September 1986, Hg. D. Simon, Frankfurt a. M. 1987, 485-503 (I us commune Sonderhefte 30$)$. 
uzasadniania tego charakteru (zresztą w określonych kontekstach nieraz skuteczne) dokonywane $z$ perspektywy związanych $z$ tymi teoriami kultur prawnych, a podejmowane $\mathrm{w}$ oparciu o kategorie societas perfecta czy ordinamento giuridico primario, wychodzą z założenia, że Kościół to status sui generis ${ }^{29}$. Ale przy takim przetłumaczeniu Kościoła ginie jego teologalna natura, zaś prawo jest tylko konsekwencją przyjętej (filozoficznej, politycznej, prawnej) koncepcji Kościoła. Jest wtedy strukturą, którą można rozpatrywać niezależnie od dokonujących się $w$ jej ramach zjawisk (właśnie prawnych) ${ }^{30}$, przez które Kościół przecież się realizuje. Prawu kościelnemu zapewnia się wtedy miejsce w kulturze prawnej za cenę rezygnacji $z$ tego, co nie przystaje do przyjętych kryteriów, a co właśnie może być dlań charakterystyczne i co wlaściwie dopiero czyni plodnym pytanie o miejsce prawa w kulturze prawnej. Dodajmy jeszcze, że nie uwzględnia się wtedy złożoności zjawiska prawnego.

To samo trzeba powiedzieć o próbach naświetlenia zagadnienia w oparciu o kategorię analogii ${ }^{31}$.

Stąd w rozważaniach naszych musimy wyjşć od założenia, że prawem jest to, co odnośna grupa społeczna uznaje za prawo, i tym samym przyjąć, że obecność Kościoła oznacza zawsze zarazem obecność jego prawa. Pytanie natomiast brzmi, czy i jak daje się zauważyć obecność prawa kanonicznego w kulturze prawnej odnośnego regionu.

Podejmując to pytanie trzeba przypomnieć, że prawo Kościoła kształtowało się $w$ kontakcie $z$ zastaną kulturą prawną. Wlaśnie dlatego, że prawo chrześcijan nie zależało od prawa „tego świata" i nie było skrępowane rozunieniem prawa $w$ świecie, pozostawało ono otwarte na różne pojęcia i formy prawne wyksztaltowane $w$ świecie, a przydatne dla wyrażenia spolecznych treści doświadczenia chrześcijańskiego oraz dla organizacji zgromadzeń i gmin. W kulturze prawnej chrześcijanie znajdują pojęcia nadające się do wyrażenia ich własnej świadomości. Przydatność tych pojęc prawnych świadczy o immanentnym prawnym wymiarze wspólnoty i pozwala go wyartykułować w sposób komunikatywny, a zarazem - z drugiej strony - dzięki temu wyartykułowanemu wymiarowi chrześcijaństwo wchodzi na orbitę kultury prawnej. Oczywiście, nie nazwa jest ważna, lecz treść nią oznaczona. Nazwy przejęte nabierają na gruncie chrześcijańskim nieraz nowych treści, odpowiednio do podstaw relacji międzyosobowych. Na wyraźniejsze uświadomienie sobie tych treści przez chrześcijan wpływa też konfrontacja $z$ prawem środowiska, zwłaszcza zaś z prawem Starego Testamentu mającym charakter sakralny. W tej konfrontacji prawo kościelne jest chlonne, ale okazuje się, że ludzie inspirowani wiarą mają też coś do powiedzenia, zwłaszcza na temat

29 Tak P. A. d'Avack, Trattato ..., 207.

so ,... la Ecclesia deorsum quale ordinamento giuridico costituisce una semplice superstruttura o, meglio, una mera rappresentazione formale della Ecclesia deorsum" - P. A. d'Avack, Traftato ..., 85.

"11 Krytycznie G. Ghirlanda, $I$ diritto civile ",analogatum princeps" del diritto canonico?, Rassegna di Teologia 16 (1975) 588-594. 
sensu prawa - i to jeszcze zanim prawo kościelne stało się jednym z praw rządzących Europą. W każdym podręczniku historii doktryn politycznych i prawnych czy historii filozofii prawa jest mowa o ideologii Nowego Testamentu, o Ireneuszu, Orygenesie, Tertulianie, a następnie Euzebiuszu, Ambrożym, Augustynie.

Ostatnim z uczonych Kościoła, których w tych podręcznikach znajdujemy, jest Franciszek Suarez. Wiąże się to niewątpliwie z wycofaniem się prawa kanonicznego intra muros Ecclesiae. Pozbawione roli, jaką odgrywało w średniowieczu, prawo kanoniczne „czuje się" jakby gorszym prawem, nie tak skutecznym jak świeckie, a ponadto zagrożone różnymi odmianami jurysdykcjonalizmu. Stąd apologetyczna postawa kanonistyki, jak zresztą całej eklezjologii. Chodzi o obronę zagrożonych pozycji, prowadzoną metodą (już nie kwestii, lecz) tez ${ }^{32}$, co ją czyni niezdolną do nawiązania dialogu $z$ kolejnymi prądami filozoficznoprawnymi. Ponieważ $w$ tej tendencji trzeba podkreślać to, co prawo kościelne ma wspólnego $z$ prawem świeckim, a odrębności wypychać w sferę metajurydyczną, prawo kościelne nie jest w stanie inspirować, może jedynie czerpać i cieszyć się, gdy udaje się je dostosować.

W tych zabiegach chodzi o uznanie prawa kościelnego wzgl. o jego postawienie na poziomie odpowiadającym współczesnej kulturze prawnej. Nie przecząc wagi tych dążeń trzeba jednak eklezjologicznie poprawnie ustawić perspektywę obecności prawa kościelnego w kulturze prawnej. Kościół bowiem nie istnieje dla siebie, lecz dla świata. „Interes” Kościoła istnieje nie ze względu na sam Kościól, lecz ze względu na świat. Myśl kanoniczna - i chyba nie tylko - wciąż jest skupiona na samym Kościele, podczas gdy jej właściwym odniesieniem winna być historia zbawienia. Już w Pawłowych wywodach o prawie chodzi o prawo „w ogóle” jak ono ma się ku zbawieniu czlowieka. Kościół kształtuje własne struktury prawne, by być czytelnym znakiem dla świata, porządek na własnym podwórku ma znaczenie właśnie w tej perspektywie. Acies bene ordinata nie jest celem dla siebie, nie chodzi o konkurencyjny porządek prawny, lecz o przyczynianie się do tego, by „prawo zawsze prawo znaczyło".

To przyczynianie się nie może oznaczać chęci wprowadzania się prawa kościelnego $w$ państwowy porządek prawny jako jego korektura, czy uzupełnienie. Nie chodzi o to, by ono obowiązywało na forum państwowym. Prawo kościelne może $i$ powinno być obecne w kulturze prawnej jako wewnętrzne prawo Kościola, a więc przy konsekwentnym zachowaniu dualizmu chrześcijańskiego i uszanowaniu autonomii kultury, w tym przypadku kultury prawnej. Mówiąc inaczej: do zagadnienia ,prawo kanoniczne a kultura prawna" trzeba w sposób zasadniczy stosować zasady ewangelizacji. W świetle konstytucji Gaudium et spes sprowadzają się

32 E. Corecco, Considerazioni sul problema dei diritti fondamentali del cristiano nella chiesa e nella societa. Aspetti metodologici della questione, w: Les Droits Fondamentaux du Chrétien dans l'Eglise et dans la Societé. Actes du IVe Congres International de Droit Canonique, publiè par E. Corecco, H. Herzog, A. Scola, Fribourg-Freiburg-Milano 1981, 1207-1234. 
one w naszym kontekście do dwóch: a) Kościół stara się przynieść pomoc społeczeństwu (n. 42), b) Kościół doznaje pomocy od świata (n. 44).

Kultura prawna jest - jak na to już zwracaliśmy uwage - zjawiskiem złożonym, wielowarstwowym. Wielowarstwowe jest też pojęcie prawa. Nie wchodząc tutaj w problematykę pojęcia prawa stwierdźmy, że zawiera ono warstwę ideową i warstwę realną (która $\mathrm{z}$ kolei też jest wielowarstwowa). W warstwie ideowej nie znajdujemy konkretnych przepisów, ustalonych reguł, lecz pewną podstawową ideę - idea prawa, podobnie jak idea dobra - którą należy zawsze i wszędzie realizować, do której należy zmierzać ${ }^{33}$. Warstwa realna prawa to jego konkretne fenomeny, najczęściej prawo pozytywne. Realnie istniejące prawo jest zjawiskiem doświadczalnym. Z niego drogą indukcji wyprowadza się definicję prawa. Ze względu na złożoność prawa dochodzi się do wielości definicji. Dowodzą one, że również próby skonstruowania definicji czysto formalnej prowadzą do definicji materialnej ${ }^{34}$, do prawa jako do pewnej rzeczywistości życia społecznego. Problemami tej rzeczywistości zajmują się różne dyscypliny naukowe, prawnicze, spoleczne, filozoficzne, a także teologia. Ostatecznie chodzi w nich o to, by wśród tych wszystkich aspektów i płaszczyzn badawczych pokazać, jak w nich realizuje się „prawo w prawie”.

Prawo kanoniczne stanowi jedną $z$ prób realizacji "prawa w prawie" i dlatego jest porównywalne $\mathrm{z}$ innymi próbami. Ta kościelna realizacja „prawa w prawie" dokonuje się $w$ kontakcie $z$ doświadczeniem narodów i korzysta $z$ tego doświadczenia. Nie może nie być otwarta na nie. Ocenie historycznej podlega, czy i gdzie lepiej udaje się ta realizacja ,prawa w prawie".

Oceny dokonuje się zawsze $z$ jakiegoś odniesienia, w tym przypadku $\mathrm{z}$ punktu widzenia przyjętych założeń ideowych. Właśnie w warstwie ideowej następuje interferencja kultur prawnych, krystalizują się wyznaczniki procesów formowania się prawa realnie istniejącego. Tę warstwe winniśmy mieć w pierwszym rzędzie na oku, gdy chodzi o kontakt prawa kanonicznego z kulturą prawną. Pytanie brzmi: czy i co prawo kanoniczne ma w sferze ideowej do powiedzenia?

Warstwa ideowa prawa to jego antropologiczne, spoleczne i ontologiczne założenia (obraz człowieka, pojmowanie życia społecznego, postrzeganie struktur rzeczywistości) oraz oczekiwania powszechnie wiązane z prawem (sprawiedliwość, słuszność, praworządność...). Jest to więc warstwa, na której kształtują się podstawowe zasady prawa (mamy oczywiście na uwadze wieloznaczność tego pojęcia) ${ }^{35}$. Spoczywają one u podstaw świadomości prawnej odnośnych grup społecznych, wyznaczają cele prawa, determinują jego pojęcie, kształtują praktykę i decydują ostatecznie o profilu odnośnej kultury prawnej.

${ }^{33} \mathrm{H}$. Henkel, Einführung in die Rechtsphilosophie. Grundlagen des Rechts, München² 1977,17 ns.

${ }^{34} \mathrm{H}$. Henkel, tamże, 13.

35 G. del Vecchio, Sui principii generali del diritto, nuova ed., Milano 1958. 
Latwo dostrzec, że obracamy się tutaj wśród zagadnień zajmujących istotne miejsce $w$ nauczaniu chrześcijańskim, a zarazem też najbardziej w historii myśli ludzkiej dyskutowanych. Zwróćmy np. uwagę na rozbieżność opinii na temat sprawiedliwości. Pytanie o sprawiedliwość przyrównuje się do Piłatowego „co to jest prawda?” ${ }^{36}$. Podejmuje je chrześcijaństwo i usiłuje $\mathrm{w}$ świetle wiary powiedzieć ludziom, co człowiek winien drugiemu, jakie zasady winny stać u podstaw praktyki społecznej. Kościół prowadzi ze światem dialog o sprawiedliwość całym swoim przepowiadaniem, zwłaszcza swoją doktryną społeczną. Ale Kościół byłby niewiarygodny, gdyby głoszonych przezeń podstawowych zasad życia społecznego. i prawa nie stosowat we własnym prawie. Prawo kościelne to poligon katolickiej nauki społecznej. Dyskwalifikowałoby się, gdyby zachodził rozbrat między nim i zasadami głoszonymi przez Kościół. Sądzę, że znaczenie prawa kanonicznego jako przykładowa realizacja zasad chrześcijańskich jest raczej mało doceniane, wciąż bardziej dominują aspekty dobrej, wewnętrznej organizacji niż świadectwa (przy czym - podkreślmy aspekty te nie wykluczają się, lecz wzajemnie się warunkują).

A właśnie spojrzenie $z$ punktu widzenia świadectwa wydaje się ogromnie instruktywne. Dla Kościoła pociąga ono za sobą konieczność ciąglej samorefleksji, czy jego prawo $-z$ jednej strony — odpowiada własnym antropologicznym i eklezjologicznym założeniom, oraz $-z$ drugiej strony - czy wierne tym założeniom korzysta $w$ sposób optymalny (właśnie ze względu na świadectwo) z osiągnięć kultury prawnej (optymalny nie znaczy maksymalny, lecz zróżnicowany ze względu na własne. zasady i założenia, czyli chłonny, a zarazem krytyczny). Głoszone przez Kościół zasady życia społecznego są pomyślane jako pomoc dla sprawiedliwego urządzenia świata. Często są postulatem, czasem korekturą,. zwłaszcza pod adresem systemów, w których nie szanuje się podstawowych zasad życia społecznego. Ale przecież współcześnie można - przynajmniej $w$ tzw. kulturze europejskiej - mówić o osiągniętym konsensie np. w kwestii praw człowieka. Stąd Kościół głosząc np. podmiotowość osoby ludzkiej musi być otwarty na realne osiągnięcia kultury prawnej w tym zakresie i okazać gotowość na wprowadzenie ich na własne forum prawne.

Nie należy przy tym jednak zapominać o właściwej chrześcijaństwu odrębności porządku religijnego i społecznopolitycznego. Odrębności te, wiążące się $z$ odmiennymi dobrami realizowanymi w tych porządkach, a tym samym $z$ ich sensem $i$ celem, nie pozostają bez wplywu na podstawowe zasady prawa. Wprawdzie jako zasady podstawowe pozostają one wszędzie ważne, ale (1) zostają wypełniane różną treścią oraz (2) różnie akcentowane i uszeregowane.

Spróbujemy to zilustrować na przykładzie sprawiedliwości. Suum: cuique tribuere - to węzłowa idea każdego prawa. Ale właśnie przy pojmowaniu tego suum cuique zaczynają się rozbieżności. Przyjmując

36 H. Henkel, Einführung ..., 395. 
wbrew Kelsenowi ${ }^{37}$, że nie jest to czcza formuła (Leerformel) ${ }^{38}$, lecz ma relacjonalny sens ${ }^{39}$, trzeba odwolując się do doświadczenia stwierdzić, że w życiu społecznym może ona funkcjonować, jeśli da się kontrolować i egzekwować. Stąd możliwość kontroli i egzekwowania weszła w orbitę kryteriów sprawiedliwości ${ }^{40}$. Kryteria sprawiedliwości wypracowuje się przeto $w$ doświadczeniu społecznym jako wynik kompromisu społecznego mającego zapewnić pokój i porządek spoleczny.

o suum cuique obowiązującym w Kościele decydują wartości w nim i przezeń realizowane. Kościelna praktyka sprawiedliwości to świadectwo doznanej miłości Bożej. To, co chrześcijanin winien drugiemu człowiekowi, a Kościół światu, to to, co dla świadectwa i przekazywania otrzymał. Prawo kościelne nie może nie liczyć się z tym, że nie ma sprawiedliwości, dopóki nie jest ona nasycona miłością. We wspólnocie głoszącej przykazanie miłości nie można konstruować sprawiedliwości $z$ jego pominięciem. Prawo kościelne musi formułować właśnie wymogi takiej sprawiedliwości. Założenia antropologii chrześcijańskiej każą zakładać opartą o łaskę możliwość jej realizacji, a zarazem liczyć się ze słabością ludzką i z mniej lub bardziej zawinionym niepowodzeniem ${ }^{41}$.

Właśnie w tym momencie prawo kościelne sięga do doświadczeń kultury prawnej. Konfrontowane ze słabością ludzką i stojąc na straży tożsamości wspólnoty ustala pewne minimalne granice uznane za nieprzekraczalne. Dla zapewnienia realizacji sprawiedliwości na własnym forum konkretyzuje jej wymogi dla przewidywanych, generalnie ujętych przypadków, a więc wedle pewnej obliczalnej przeciętnej. Precyzuje je wedle racjonalnych kryteriów w sposób umożliwiający kontrolę i sankcjonowanie. Korzyść $w$ postaci skuteczności prawa osiągnięto za cenę kompromisu: miejsce wysokich wymagań sprawiedliwości ewangelicznej zajęly wymagania „trzeźwe”, określone, nieodzowne minimum.

Stoją za tym nie tylko względy techniczne: jak ująć w prawie pozytywnym radykalne wezwanie Ewangelii? Rzecz w trudności uznania wezwania ewangelicznego za prawne. Po prostu to, co nie odpowiada przyjętemu w kulturze prawnej rozumieniu sprawiedliwości (implikującemu jej sprawdzalność i egzekwowalność) zostaje wypchnięte w sferę metakanoniczną. Miejsce "radykalnego" prawa, wobec którego wierny staje ze swoimi słabościami jako wobec wezwania, zajmuje prawo z już wkalkulowaną slabością, ale zarazem $\mathrm{z}$ bezwzględnym roszczeniem. Zamiast ideału i wezwania, by wierny wedle najlepszej woli $i$ wiedzy podejmował decyzje i w ten, acz niedoskonały, sposób realizował prawo, decyzję przejmuje

${ }^{37}$ Reine Rechtslehre, Wien² 1960, 366.

38 W. Wald t ein, Ist das "suum cuique" eine Leerformel?, w: Ius humanitatis. Festschrift A. Verdross, Hg. H. Miehsler ..., Berlin 1980, 285-320.

${ }^{39}$ H. Henkel, Einführung ..., 403-419.

¿ R. Sobański, Erwägungen zum Ort des Kirchenrechts in der Rechtskultur, Archiv f. Kath. Kirchenrecht 155 (1986) 3-15.

${ }^{4} \mathrm{~K}$. Demmer, Das Verhältnis von Recht und Moral im Licht kirchlicher Dispenspraxis, Gregorianum 56 (1975) 681-731, zwłaszcza 695-704. 
niejako samo, już dostosowane do przeciętności prawo, jawiące się jako wola prawodawcy, którą należy tylko wykonać.

Od prawa świeckiego „nauczyło się" więc prawo kościelne, że aby realizować sprawiedliwość (czy też inne wartości etyczne) trzeba ją skalkulować, obliczyć według pewnej przeciętnej, sprowadzić do poziomu akceptowanego. Tym samym ze względów racjonalnych zostaje osłabiony radykalizm ewangeliczny, rozróżnia więc między (prawnymi) obowiązkami ex iustitia i (pozaprawnymi) ex caritate. Praktycznie nie ma innego wyjścia, nie mniej jednak stanowiąc prawo ustawodawca kościelny nie może zapomnieć o tym, co głosi jako nauczycieliwiary. Usiłuje więc chrześcijańskie elementy wprowadzić w prawo przez ustalenie zobowiązań wynikających $\mathrm{z}$ rad ewangelicznych, uzupełniać zasadę sprawiedliwości (pojętą jako sprawiedliwość naturalną) zasadą milosierdzia, dokonać preferencji wśród zasad prawa. Doświadcza przy tym ograniczoności środków prawnych (podobnie jak w przepowiadaniu wiary musi uporać się z nieadekwatnością pojęć). Bardziej niż prawodawca świecki (który może swoją rolę uznać za odegraną, gdy zabezpieczył pokój społeczny) musi Kościół starać się o zgodność realnego prawa $z$ głoszoną ideą. Korzyści, jakie czerpie z kultury prawnej, są ewidentne. Na razie nie widać, by prawo świeckie mogło czerpać z prawa kościelnego. To skłania mnie do sformułowania następujących tez końcowych:

1. Prawo kościelne jest skazane na korzystanie $z$ osiągnięć kultury prawnej (podobnie jak całe przepowiadanie Kościoła jest skazane na dorobek kultury ludzkości). Pytanie brzmi zawsze, jak daleko osiągnięcia te są przydatne dla wyrażenia kościelnej „prawdy prawnej”. Przydatność ta zależy od stanu nauk zarówno prawnych, jak i kościelnych, to znaczy, że prawo kościelne zajmuje wobec kultury prawnej postawę otwartą i chłonną, acz zróżnicowaną i nie bezkrytyczną.

2. Uniwersalne posłannictwo Kościoła pociąga za sobą otwartą postawę wobec kultury prawnej każdego środowiska, w którym Kościół istnieje i działa. Nawiązanie do miejscowej kultury prawnej i spożytkowanie dorobku kultur regionalnych rządzi się zasadami stojącymi u podstaw relacji Kościół powszechny - Kościoły partykularne ${ }^{42}$. Wpływ prawa rzymskiego i germańskiego na kościelne $z$ jednej, romanizacja prawa barbarzyńców poprzez Kościół czy też wpływ prawa kanonicznego np. na prawo polskie $z$ drugiej strony dowodzi, jak owocny może być kontakt Kościoła $z$ kulturą prawną środowiska.

3. W ostatnich wiekach obecność prawa kanonicznego w kulturze prawnej jest najwyżej bierna. Usiłuje ono zapewnić sobie obecność poprzez dostosowanie się. Nie przecząc, że obecności winna zawsze towarzyszyć gotowość do uczenia się, trzeba jednak dostrzec, że z powodu tej defensywnej postawy prawo kościelne nie inspiruje kultury prawnej. Dodajmy, że zapewnienie tej (biernej) obecności udaje się tylko częściowo - i to

42. W. Aymans, Die Communio Ecclesiarum als Gestaltgesetz der einen Kirche, Archiv f. Kath. Kirchenrecht 139 (1970) 69-90. 
nie tylko dlatego, że kształtujące myśl prawną założenia filozoficzne są (wzgl. wydają się) dla Kościoła nie do przyjęcia, lecz zwłaszcza dlatego, że wskutek przyjętej postawy wyłącznie recepcyjnej przemilcza lub przesuwa w sferę metajurydyczną wszystko to, co nie mieści się w optyce współczesnych nauk prawnych.

4. Niewątpliwie, nie Kościół jest miejscem rozwoju nauk prawnych, a kultura prawna cieszy się autonomią. Ale wspólnota, określana jako Ecclesia iuris, jest taką nie wskutek przejęcia prawa $z$ zewnątrz, lecz $z$ powodu wlasnego, immanentnego wymiaru prawnego. (Bez niego autonomiczne prawo kościelne nie miałoby racji bytu, a organizacyjne sprawy Kościoła mogłoby regulować prawo wyznaniowe). Stąd należałoby uznać, że wpisany $\mathrm{w}$ historię prawa Kościól ma w niej coś do powiedzenia zarówno $\mathrm{w}$ warstwie ideowej, jak też $\mathrm{w}$ praktycznej realizacji prawa. Brak inspirującej obecności musi dać do myślenia tym bardziej, że podstawowe zagadnienia prawa są $w$ świecie wciąż dyskutowane, nauki prawne wykazują szczególną podatność na wpływy różnych filozofii, a w świecie zjednoczonych narodów nie brak interferencji prawa.

5. Na nie jedno-, lecz dwukierunkowy kontakt prawa kanonicznego $z$ kulturą prawną można liczyć dopiero wtedy, gdy kanonistyka przejmie metodę zastosowaną na Soborze Watykańskim II, na którym Kościół rezygnując $\mathrm{z}$ pokazywania się ratione status usiłował przedstawić, jak tylko mógł, czym on naprawdę jest według własnego przekonania wiary. Również $w$ prawie kanonicznym trzeba zdobyć się na przemyślenie w świetle wiary Kościoła własnych założeń i celów, aby nadać jego prawu kształt najbardziej im odpowiadający i by móc nawiązać dialog ze światem prawa. Dialogu tego nie nawiąże się przez samo powielanie prawa świeckiego na forum kościelnym, lecz przez otwarte na świat przemyślenie własnych zalożeń, w tym także „nowej sprawiedliwości”. Tylko wtedy obecność prawa kanonicznego $\mathrm{w}$ kulturze prawnej może być nie tylko reproduktywna, lecz także produktywna ${ }^{43}$.

6 . Także $z$ tego punktu widzenia rysuje się paląca konieczność wypracowania teorii prawa kościelnego ${ }^{44}$. Chodzi 0 teorię prawa Kościoła według jego własnego credo Ecclesiam, a nie o wtłoczenie w ramy jakiejś apriorycznej teorii. Bałamutne są wołania o odteologizowanie prawa kościelnego czy zarzuty przeciw jego rzekomej teologizacji ${ }^{45}$. Nie chodzi o "teologizowanie”, lecz o uwzględnienie jego ontologicznych i teologicznych założeń, dzięki którym dialog z kulturą prawną staje się możliwy i sensowny.

43 Dla przykladu można tu wskazać na prawne znaczenie milosierdzia jako czynnika współdeterminującego sprawiedliwość - H. Henkel, Einführung ..., 419.

44 R. Sobański, Zagadnienie wstepu do nauki prawa kanonicznego (Uwagi na marginesie dekretu Optatam totius Nr 16, 4), Pr. Kan. 17 (1974) n. 1-2, 3-30, zwlaszcza 26-30.

${ }_{45} \mathrm{~W}$ wysuniętym przez T. I. Jimenez-Urresti (Prawo kanoniczne $i$ teologia, dwie odrębne nauki, Concilium 1-10, 1966) 67, Poznań 1969, 456-461) postulacie „odteologizowania" prawa kościelnego chodziło nie o pozbawienie go „treści 


\section{Diritto canonico e cultura giuridica}

Si presenta la versione polacca di una relazione tenuta nell'ambito dei seminari sul tema „Scienza giuridica e diritto canonico" à l'Università di Torino 2. 5. 1990. 11 testo originale viene pubblicato nel volume sullo stesso tema curato da Rinaldo Bertolino, Torino 1991. Ci presentiamo le osservazioni finali.

1. Il diritto canonico non puo non giovarsi dello sviluppo della cultura giuridica (allo stesso modo che l'intero magistero della Chiesa non puo non giovarsi del patrimonio culturale dell'umanità). Immutato è il quesito di fondo: in che misura queste vicende possono riuscire utili ad esprimere la „verità" ecclesiale. L'utilità dipende dallo sviluppo delle scienze giuridiche, come di quelle ecclesiali: il che significa che il diritto canonico ha, di fronte alla cultura giuridica, un atteggiamento aperto ed assorbente, pur se differenziato e non privo di critica.

2. Per sua vocazione universale la Chiesa ha un atteggiamento aperto di fronte alla cultura giuridica d'ogni ambiente in cui esse è presente ed agisce. Il riferimento alla cultura giuridica locale e i rapporti con le vicende delle culture regionali sono omogenei con i principi fondamentali della relazione Chiesa universale-Chiese locali. L'influsso del diritto romano e di quello germanico sul diritto canonico, da un lato; la romanizzazione del diritto dei barbari attraverso la Chiesa 0 , anche, l'influsso del diritto canonico p. es. sul diritto polacco dall'altro, dimostrano quanto il contatto della Chiesa con la cultura giuridica dell'ambiente possa ruiscire fecondo.

3. Negli ultimi secoli la presenza del diritto canonico nella cultura giuridica è, al massimo, passiva. Cerca d'assicurarsela una presenza mediante l'adattamento. Se anche sia vero che qualunque presenza debba accompagnarsi con la disponibilità ad imparare, occorre riconoscere che questa posizione unicamente difensiva non consente al diritto canonico di incidere e di ispirare la cultura giuridica. Inoltre, l'esito di questa presenza (passiva) è parziale, non solo perché le premesse filosofiche che fondano il pensiero giuridico sono (o sembrano essere) per la Chiesa inaccettabili, ma perché, in seguito all'atteggiamento esclusivamente recettizio, si corre il rischio di trasferire nell'ambito metagiuridico tutto cio che non si ritrovi nell'ottica delle attuali dottrine giuridiche.

4. Non c'è dubbio che la Chiesa non sia l'ambiente topico di sviluppo delle scienze giuridiche e che la scienza giuridica goda di una sua piena autonomia. Ma la comunione ecclesiale, non di raro definita Ecclesia iuris, non lo è in seguito alla recezione del diritto ab extrinseco, ma in forza della propria immanente dimensione giuridica. (Senza di essa non avrebbe ragion d'essere un autonomo diritto canonico, ed i problemi organizzativi della Chiesa potrebbero essere risolti alla stregua del solo diritto ecclesiastico dello Stato). Si deve quindi riconoscere che la Chiesa, iscritta nella storia umana del diritto, ha qualche cosa da dire nella sfera del diritto, sia nella sua dimensione ideologica che in quella della sua realizzazione pratica. L'assenza di un ruolo ispiratore del diritto canonico sulla scienza giuridica contemporanea dovrebbe dar a pensare per la più che $\mathrm{i}$ fondamentali problemi giuridici vengono continuamente discussi dai cultori di diritto: viviamo tuttavia in un mondo di nazioni sempre più unite nel quale le interferenze di differenti teorie e sistemi giuridici tendono ad aumentare e le dottrine giuridiche si rivelano particolarmente suscettibili agli influssi di molteplici filosofie.

5. Su un contatto non unidirezionale ma bilaterale del diritto canonico con la cultura giuridica si potrà contare soltanto allora, quando la canonistica abbia

teologicznej", lecz o wydobycie jego autentycznej treści teologicznej. Takiemu postulatowi można tylko przyklasnąć. Trudno natomiast traktować na serio etykietowanie jako teologizowanie wszystkich tych stanowisk, wedle których myśl kanonistyczna nie może obejść się bez kategorii eklezjalnych czy wręcz uniezależnić się od nich. 
fatto proprio il metodo del Concilio Vaticano II, durante il quale la Chiesa ha rinunciato a presentarsi ratione status, ed ha invece cercato di esporre la sua natura secondo la propria convinzione di fede. Anche nel diritto canonico bisogna finalmente decidersi ad una riflessione profondo sulla Chiesa alla luce della fede, sulle proprie radici e finalità, per poter realizzare il diritto ecclesiale nel modo più coerente e per potere, per cio stesso, dialogare con le altre culture giuridiche. Il dialogo non nascerà da una passiva traslitterazione, quasi a ricalco, del diritto civile nell'ambiente ecclesiale, ma attraverso una franca ed aperta meditazione sulle proprie premesse ontologiche, le proprie peculiarità, le proprie esigenze: anche quelle di una „nuova giustizia”. Soltanto allora la presenza del diritto canonico nella cultura giuridica potrà essere non solo riproduttiva, ma anche produttiva.

6. Anche sotto questo punto di vista appare urgente la necessità di una robusta elaborazione di una teoria generale del diritto canonico. Si tratta di una teoria del diritto della Chiesa secondo il suo proprio ,credo Ecclesiam”, non già elaborata all'interno di rigide teorie aprioristiche. Troppo generiche e scarsamente feconde le prese di posizione a favore di una deteologizzazione del diritto ecclesiale e, al contrario, le obiezioni stesse contro una presunta sua teologizzazione. Non si tratta invero di una „teologizzazione", ma di prendere in seria considerazione i principi teologici, grazie ai quali il dialogo con la cultura giuridica diventa possibile e razionale. 